JURNAL RESPIRASI

$J R$

Vol. 1 No. 1 Januari 2015

\title{
Seorang Laki-laki Usia 16 Tahun yang Mengalami Drowning dan Pneumotoraks Paska Pemasangan Ventilator Mekanik
}

Ira Nurrasyidah, Winariani Koesoemoprodjo

\begin{abstract}
Background; Drowning is defined as respiratory impairment due to submersion/immersion in liquid. The liquid/air interface at the entrance of the airway prevents the victim from breathing air. According to the World Health Organization (WHO), 0.7\% of all deaths worldwide - or more than 500,000 deaths each year - are due to unintentional drowning. Drowning is the second leading cause of unnatural death after road traffic injuries. Most of these deaths occur in countries with low or middle per capita income. Case; A16-years-old man rescued after drowning in the mud puddle for 15 minutes. He was unconscious, cyanosis, dyspnea and cough with blood and mud. After receiving oxygen in the nearest hospital he got conscious but still dyspnea. He came to our hospital and after undergone several examination we concluded that he had lung edema, ARDS and pneumonia aspiration. Patient immediately intubated and got mechanical ventilation. Five days later patient encounter pneumothorax on the right hemithorax, maybe due to barotrauma and we perfomed a chet tube insertion for three days. Patient had a good progression, there was no deficit neurologic and injury in the other organ. On follow up five months after patient hospitalized revealed normal condition on chest $x$ ray.
\end{abstract}

Key words: Drowning, Pneumothorax, Pneumonia

\section{PENDAHULUAN}

Definisi drowning terbaru berdasarkan WHO tahun 2002 yaitu proses terganggunya pernapasan dikarenakan perendaman atau pencelupan di air. Proses drowning dimulai dengan adanya gangguan pernapasan karena saluran napas terendam di permukaan air (submersion) atau adanya percikan air pada muka (immersion). Jika orang tersebut berhasil diselamatkan maka proses drowning akan terhenti maka disebut non fatal drowning. Sedangkan jika kematian terjadi akibat drowning maka disebut fatal drowning. ${ }^{1}$

Beberapa modifikasi definisi berdasarkan Model, tahun 1981 yaitu drowning didefinisikan sebagai kematian akibat asfiksia yang disebabkan proses tenggelam dalam waktu 24 jam setelah kejadian, jika korban tetap bertahan hidup setelah 24 jam dari kejadian dinamakan near drowning. Dibedakan lagi drowning dengan aspirasi atau tanpa aspirasi, begitu pula dengan near drowning, berdasarkan ada atau tidaknya proses aspirasi. Secondary drowning syndrome terjadi jika korban dapat bertahan hidup lebih dari 24 jam setelah kejadian kemudian pasien meninggal karena komplikasi Acute Respiratory Distress Syndrome (ARDS) atau pneumonia berat. ${ }^{2,3}$ Istilah near drowning, secondary drowning mulai ditinggalkan agar adanya keseragaman data dan pelaporan. ${ }^{1,2,3}$

Menurut WHO tahun 2000 drowning merupakan penyebab kedua terbanyak dari kematian tidak disengaja di seluruh dunia, setelah kecelakaan kendaraan bermotor. Angka ini lebih besar jika kematian drowning akibat banjir, kecelakaan transportasi air dan usaha pembunuhan atau bunuh diri dimasukkan. ${ }^{4}$

Berdasarkan WHO terjadi lebih dari 500.000 kematian pertahun karena drowning di seluruh dunia, sekitar 10 orang meninggal karena drowning setiap hari, anak laki-laki usia 5-14 tahun paling banyak terkena. Di Amerika drowning merupakan penyebab kematian terbanyak pada kecelakaan di usia 1-4 tahun, di Thailand rata-rata kematian anak usia 2 tahun karena drowning adalah 107/100.000. Di negara Afrika dan Amerika Tengah insidensi drowning meningkat 10-20 kali lipat. Dilaporkan 195 kematian di Inggris akibat drowning pada tahun 2008, sedangkan $43 \%$ kematian akibat drowning di dunia disebutkan terjadi di India dan China. Sayangnya angka kejadian drowning di Indonesia belum diketahui. ${ }^{1,4,5}$

Berikut ini akan dilaporkan kasus anak laki-laki, usia 16 tahun yang mengalami drowning, dan mengalami pneumotoraks paska pemasangan ventilator mekanik. 
Pasien pulang dalam kondisi stabil dan lima bulan setelah rawat inap terjadi resolusi pada foto toraks.

\section{KASUS}

Seorang laki-laki, An. A berusia 16 tahun, pekerjaan sebagai pelajar, suku Jawa, beragama Islam, berdomisili di Gresik, dirujuk ke IRD dr. Soetomo dari Rumah Sakit $\mathrm{BDH}$ dengan diagnosis near drowning dan mengeluh sesak napas.

Sesak napas dirasa sejak 3 jam SMRS. Sesak napas setelah pasien tenggelam di kolam air tawar. Pasien tenggelam kira-kira 15 menit. Ketika dikeluarkan dari kolam pasien batuk disertai sedikit darah dan lumpur. Pasien pingsan dan kebiruan. Pasien segera dibawa ke rumah sakit terdekat, setelah diberi oksigen pasien sadar. Kolam tempat pasien tenggelam tidak terlalu dalam namun mengandung lapisan lumpur yang tebal. Sebelum tenggelam pasien loncat dari pinggir kolam, ketika tidak timbul ke permukaan, pasien segera dicari dan saat ditemukan dan ditolong, posisi kepala pasien ada dalam lapisan lumpur.

Berdasarkan Pemeriksaan Fisis, keadaan umum lemah, kesadaran kompos mentis, tekanan darah 100/60 mmHg, frekuensi nafas $44 \times /$ menit, nadi $130 \times /$ menit, dan suhu aksiler $36,0^{\circ}$ C. Kepala dan leher didapatkan dispnea, tidak ada tanda-tanda anemis, ikterus, dan sianosis. Tidak didapatkan pembesaran kelenjar getah bening maupun peningkatan tekanan vena jugularis.

Pada regio toraks, inspeksi pergerakan dada simetris. Pada palpasi didapatkan fremitus raba menurun pada kedua lapang paru. Perkusi didapatkan keredupan pada kedua lapang paru. Auskultasi didapatkan suara bronkovesikuler pada kedua lapang paru. Didapatkan ronki basah halus pada kedua lapang paru.

Pada pemeriksaan jantung, suara jantung S1 dan S2 tunggal, tidak didapatkan bising jantung maupun irama galop. Pada pemeriksaan abdomen, hepar dan lien tidak teraba, tidak didapatkan massa intra abdomen dan nyeri tekan, serta bising usus dalam batas normal. Pemeriksaan anggota gerak tidak didapatkan edema, tidak didapatkan jari tabuh, serta tidak didapatkan pembesaran kelenjar getah bening di ketiak maupun lipatan paha.

Berdasarkan Pemeriksaan Laboratorium darah didapatkan Hb 16,6 g/dL, SGOT 38/ $\mu \mathrm{L}$, Leukosit 3.300/ $\mu \mathrm{L}$, SGPT $15 / \mu \mathrm{L}$, PLT $409.000 / \mu \mathrm{L}$, Albumin 3,73 g/dL. Granulosit 76,6\%, BUN 7,3 mg/dL, Hct 48,1\%, SK 0,86\%, PTT 12,3 detik, Natrium 133 mmol/L, APTT 27,9 detik, Kalium 3,3 mmol/L, GDA 286 mg/dL, Klorida 98 mmol/L. Pemeriksaan Analisa gas darah (Oksigen Jackson Rees 10 lpm): pH 7,17, $\mathrm{pCO}_{2}: 51 \mathrm{mmHg}, \mathrm{pO}_{2} 80 \mathrm{mmHg}, \mathrm{HCO}_{3}$ 16,6 mmol/L, BE - 9,9 dan $\mathrm{SO}_{2} 92,2 \%$.

Berdasarkan pemeriksaan foto toraks didapatkan perselubungan pada kedua lapang paru, dan berkonsultasi pada SMF Ilmu Penyakit Jantung, didapatkan edema paru non cardiogenic yang bisa disebabkan penyakit dasarnya (drowning), Pasien didiagnosis sementara Sesak napas,

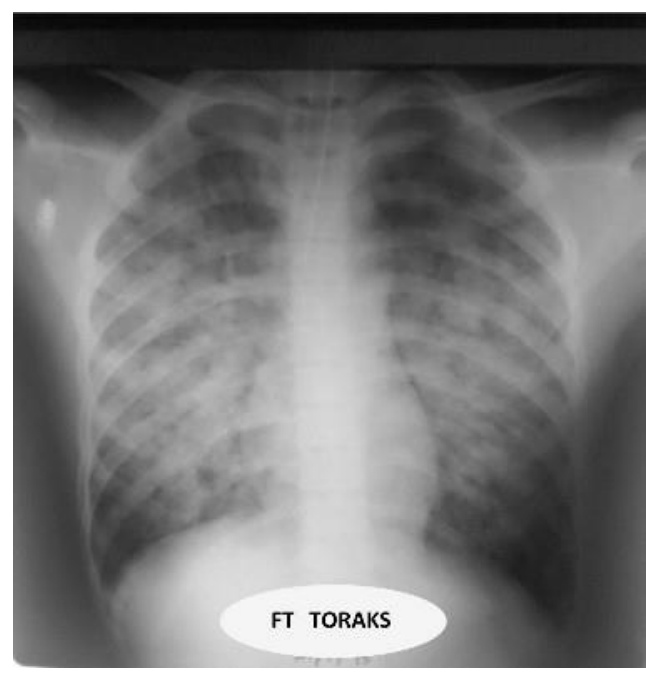

Gambar 1. Foto Toraks

Drowning, Perselubungan pada kedua lapang paru dan Hiperglikemia.

\section{PERKEMBANGAN PENDERITA}

Berdasarkan perkembangan pasien didapatkan:

1. Lima hari Pasca MRS di RSUD Dr. Soetomo didapatkan hasil:

S : : Sesak (+)

O : Ku: Lemah, Kesadaran: Sadar, baik

TD: $100 / 60 \mathrm{~N}: 100 \times / \mathrm{m}$ RR 24(ventilator)

Temp: $37.0 \mathrm{C}$

$\mathrm{K} / \mathrm{L} \quad$ : a (-) I (-) c(-) d (+)

Toraks: Cor S1 S2 tunggal murmur (-) gallop (-)

Pulmo : Inspeksi : asimetris, kanan tertinggal

Perkusi : Hipersonor/Redup

Palpasi : Fremitus raba menurun di lapang paru kanan

Auskultasi :ronki basah halus dan bronkovesikuler pada 1/3 bawah paru kiri, vesikuler menurun pada paru kanan

Abdomen : BU (+) normal, Hepar/lien tidak teraba

Ekstremitas : Hangat, kering dan merah. CRT $<2$ detik

A: Pneumotoraks dekstra paska pemasangan ventilator

Drowning

Edema paru (membaik)

ARDS (membaik)

Aspirasi Pneumonia

PDx : Konsul BTKV

Pemeriksaan sputum smear gram dan kultur aerob dan kultur darah ulang Foto Toraks, AGD

PTx : $\mathrm{O}_{2}$ (ventilator)

Posisi Slight Head up 


\section{SEQUENCE OF EVENT}

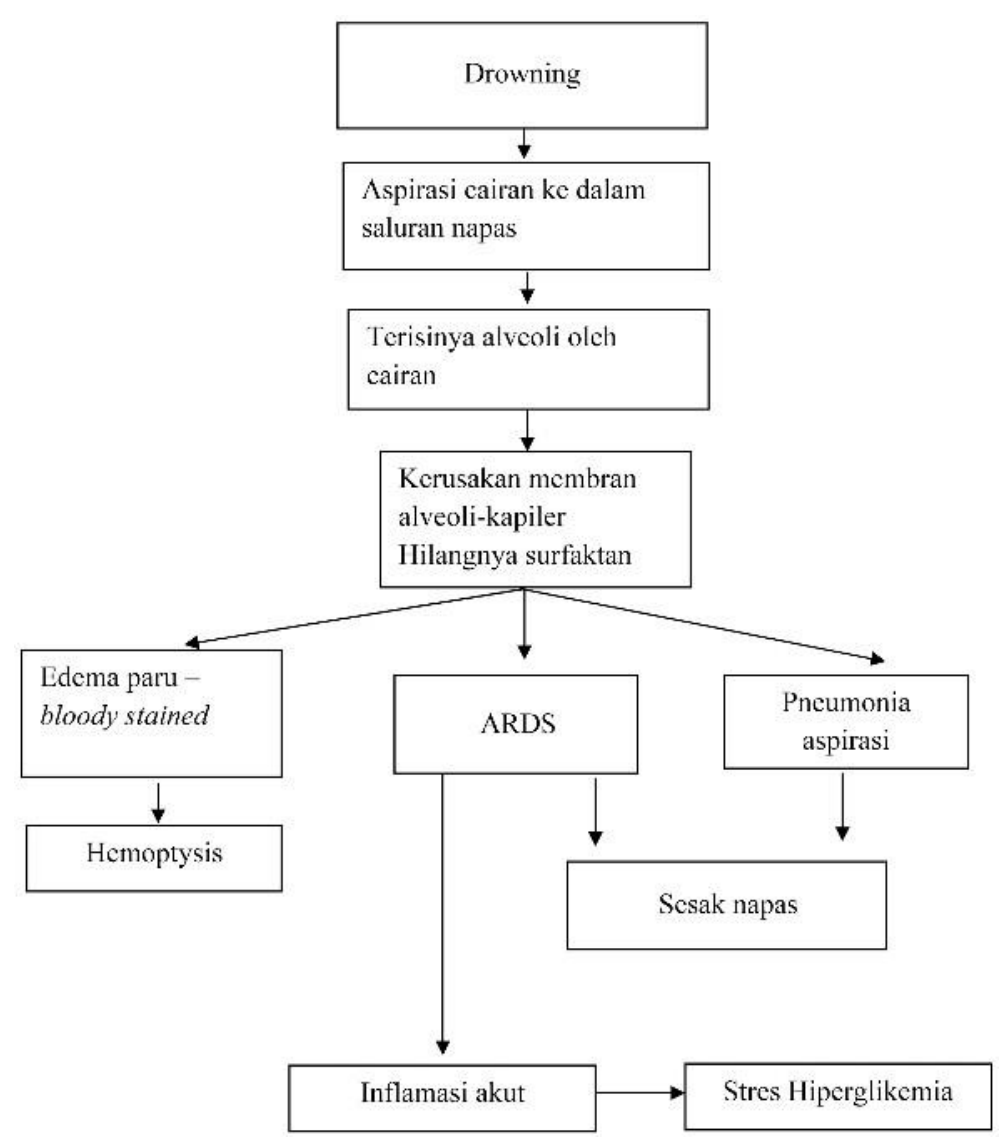

Diet sonde

Inf RD5 1500 cc/24 jam

Drip Metronidazole $3 \times 500 \mathrm{mg}$ iv

Drip Levofloxacin $1 \times 750 \mathrm{mg}$ iv

Pemasangan chest-tube+continues suction $-30 \mathrm{cmH}_{2} \mathrm{O}$ oleh sejawat BTKV

PMx: Tanda vital, Kesadaran, balance cairan dan produksi urin, pertahankan toraks drain

2. Enam hari Pasca MRS di RSUD Dr. Soetomo:

Ekstubasi

Hasil Kultur:

- Sampel Pertama

Dahak: Smear gram: Tidak ditemukan bentukan kuman

Kultur aerob: Tidak ada pertumbuhan bakteri

- Sampel Kedua

Kultur darah: Staphylococcus

Haemolyticus

Sensitif: Chloramphenicol

Dahak: Smear gram: ditemukan batang gram negatif

Kultur aerob: Klebsiella Pneumoniae Sensitif: Amikacin, Piperacillin tazobactam, Cotrimoxazol, Tetracyclin,
Chloramphenicol, Imipenem, Meropenem, Ertapenem

3. Sepuluh hari Pasca-MRS di RSUD Dr. Soetomo: Ekstubasi

S: Sesak (-) Batuk (-) demam (-)

KU baik, GCS 456

TD: $110 / 70 \mathrm{~N}: 84 \times / \mathrm{m}$ RR 18×/m Temp: 36.3

K/L: a (-) I (-) c(-) d (-)

Toraks: Cor S1 S2 tunggal murmur (-) gallop (-)

Pulmo: Inspeksi : Simetris

Perkusi : sonor/sonor

Palpasi : Fremitus raba sama

Auskultasi : vesikuler $+/+$ ronki -/-

Abdomen : BU (+) normal, Hepar/lien tidak teraba

Ekstremitas: Hangat, kering dan merah. CRT $<2$ detik

A:Drowning (perbaikan) + Pneumotoraks dekstra paska pemasangan ventilator (perbaikan)

VAP

PTx: Injeksi antibiotik (Drip Metronidazole dan Levofloxacin) $\cdot$ stop Chloramphenicol $3 \times 1$

PMx: Tanda vital, klinis

4. Pasien di rawat inap selama 12 hari di RSUD Dr. Soetomo dan kontrol 6 bulan kemudian didapatkan 
hasil:

S: keluhan (-) beraktivitas seperti biasa

O: KU baik, GCS 456

$\begin{array}{ll}\text { TD: } 100 / 70 \mathrm{mmHg} & \mathrm{N}: 82 \times / \text { menit } \\ \text { RR: } 18 \times / \text { menit } & \text { T: } 36,4 \mathrm{C}\end{array}$

K/L: a (-) i (-) c (-) d (-)

Toraks: Cor S1 S2 tunggal murmur (-) gallop

Pulmo: I/P simetris

Perkusi: sonor/sonor

Auskultasi: vesikuler/vesikuler

Abdomen: BU (+) normal, Hepar/Lien tidak teraba

Ekstremitas: akral hangat, kering, merah

A: Post Drowning

\section{PEMBAHASAN}

Drowning adalah proses terganggunya pernapasan dikarenakan perendaman paru di air. Faktor risiko yang utama dari drowning adalah jenis kelamin laki-laki (perbandingan 2:1), usia 1-4 tahun, risiko berkurang pada usia 5-14 tahun dan meningkat lagi di atas 14 tahun sampai usia dewasa muda. Pengguna alkohol, penghasilan rendah, pendidikan rendah, pedesaan, daerah yang dekat dengan akses air (dekat danau, laut atau sungai), perilaku yang berbahaya, dan kurangnya pengawasan, pekerjaan nelayan, atau adanya percobaan bunuh diri juga merupakan faktor risiko drowning. Untuk pasien epilepsi kemungkinan drowning meningkat 15-19 kali dibanding orang yang tidak memiliki riwayat epilepsi. ${ }^{1,5,6}$ Di Guangdong Cina, faktor risiko yang paling bermakna adalah berenang di sumber air alami tanpa pengawasan. ${ }^{7}$

Lokasi tenggelam berbeda berdasarkan usia, untuk anak usia 6 bulan - 1 tahun bisa terjadi di bak mandi, toilet, ember besar, mesin cuci dan bathtubs. Kebanyakan drowning pada usia dewasa muda 90\% terjadi di air tawar (sungai, danau, kolam) dan $10 \%$ di air laut. ${ }^{5}$ Pada kasus ini, sesuai dengan literatur, pasien laki-laki, usia 16 tahun dan tenggelam di kolam air tawar. Tenggelam saat berenang bersama temanteman tanpa pengawasan orang tua.

Gambaran klinis dari korban drowning tergantung banyak faktor antara lain: volume, jenis cairan yang teraspirasi, lamanya proses tenggelam dan ketepatan tindakan di tempat kejadian. Pada umumnya didapatkan gambaran kelainan paru dan neurologi yang menonjol. ${ }^{2,12}$

Pada paru keluhan berupa batuk ringan, takipneu atau edema paru yang fulminant, sesak dengan frekuensi napas kemungkinan 30-40/mnt pada 24 jam pertama dan sangat berat, ronki basah halus dan kadang juga didapatkan wheezing. Beberapa terjadi ARDS yang berhubungan dengan gagal napas dan penurunan compliance paru. Komplikasi lain pada paru meliputi atelektasis oleh karena aspirasi, pneumonia bakterial sekunder dan cedera misalnya pneumotoraks atau pneumomediastinum akibat resusitasi atau pemasangan ventilator. ${ }^{2,12}$ Pada kasus ini pasien mengeluh sesak napas, batuk disertai darah, terjadi edema paru masif dengan gejala haemoptisis, frekuensi napas $44 \times /$ menit, ronki basah halus di kedua lapang paru. Hasil analisis gas darah mengungkapkan adanya gangguan ventilasi perfusi dengan gambaran foto toraks infiltrat luas bilateral mendukung diagnosis ARDS.

Gambaran klinis pada kardiovaskuler sering terjadi cardiac arrest yang sering memberikan respons terhadap tindakan resusitasi. Pada korban yang respons terhadap resusitasi atau korban tanpa cardiac arrest sering didapatkan takikardi supraventrikuler (SVT) karena hipoksemia dan asidosis dan umumnya mengalami perbaikan jika hipoksemia dan asidosis dapat teratasi. ${ }^{10,12}$ Pada kasus ini pasien datang dengan tanda vital yang stabil, tekanan darah normal, dan nadi teratur.

Gambaran neurologi awal meliputi kejang dan gangguan status mental seperti agitasi dan koma. Pada koban mungkin didapatkan gangguan bicara, motorik, visual atau sindroma otak organik yang difus. Beberapa dari defisit neurologik ini
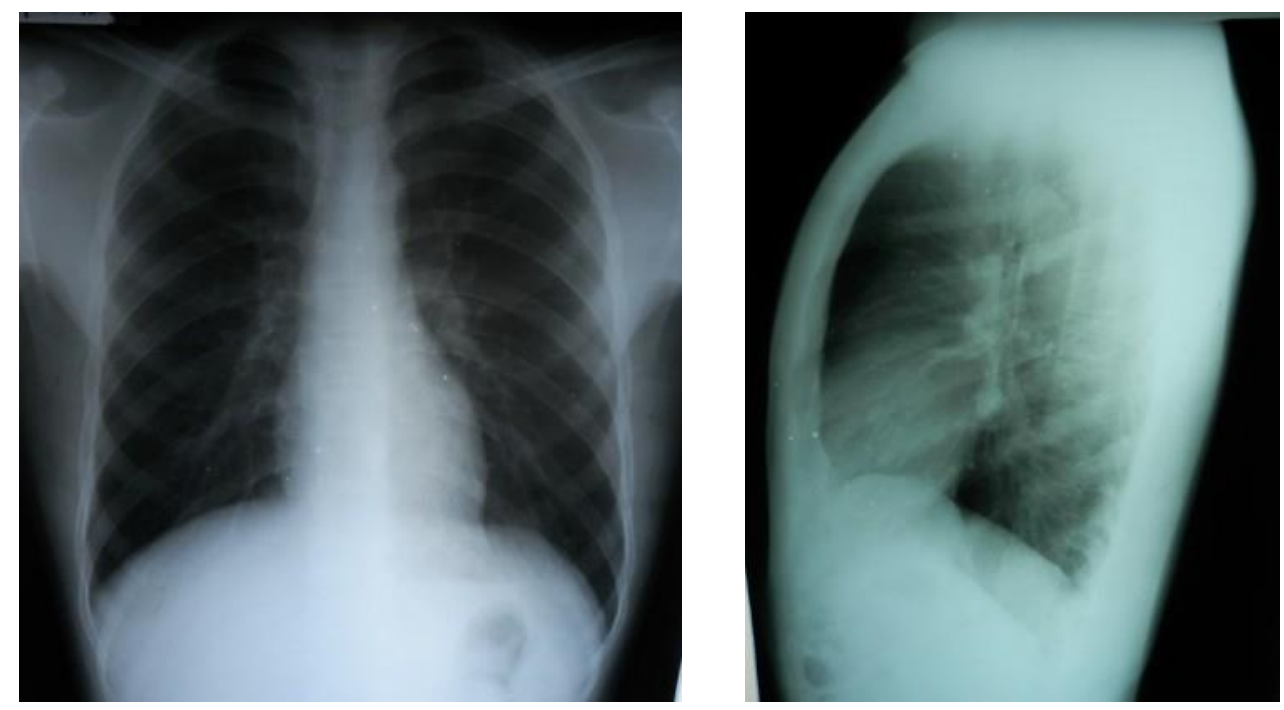

Gambar 2. Foto Toraks

Kesimpulan Gambar 2: Didapatkan dalam batas normal 
akan bertambah secara gradual dan mengalami perbaikan setelah beberapa bulan. ${ }^{10}$ Pada kasus ini, saat pasien datang ke IRD dalam kondisi sadar dan tidak didapatkan defisit neurologik. Keadaan kardiovaskuler dan neurologi yang stabil dapat dikarenakan proses tenggelam tidak terlalu lama dan pertolongan segera.

Febris (suhu lebih dari $38^{\circ} \mathrm{C}$ ) sering didapatkan pada korban dengan aspirasi yang terjadi secara signifikan, biasanya menunjukkan adanya suatu infeksi. Muntah umumnya didapatkan selama atau setelah resusitasi oleh karena distensi lambung akibat tertelannya sejumlah cairan dan udara selama drowning dan mungkin menyebabkan aspirasi cairan lambung. Manifestasi yang jarang namun dapat terjadi yaitu gagal ginjal akut. ${ }^{12}$ Pada kasus ini tidak ada febris, tidak ada muntah dan laboratorium hasil fungsi ginjal dalam batas normal.

Kelainan yang sering didapatkan pada gambaran radiologis adalah edema paru. Pada kasus yang berat didapatkan gambaran opasitas yang menyeluruh pada kedua lapang paru. Pada beberapa korban gambaran edema paru mungkin belum nampak, kadang-kadang baru tampak 24-48 jam setelah kejadian. Pada beberapa pasien gambaran radiologis yang persisten atau memburuk kemungkinan menunjukkan adanya aspirasi benda asing atau pneumonia bakterial sekunder dengan atau tanpa ARDS. Pada korban yang selamat pada gambaran radiologis didapatkan fibrosis yang persisten dan opasitas linier setelah perbaikan. ${ }^{13}$ Pada kasus ini gambaran radiologis memperlihatkan perselubungan menyeluruh di kedua lapang paru yang mengesankan edema paru.

Hasil analisa gas darah menunjukkan hasil yang bervariasi tingkat hipoksia dan asidosisnya. Gangguan natrium dan kalium umumnya ringan dan tidak memerlukan koreksi yang berarti. Leukositosis juga didapatkan pada 24-48 jam pertama dan perubahan yang signifikan dari hematokrit dan hemoglobin jarang terjadi. ${ }^{12}$ Hasil analisis gas darah pada pasien ini menunjukkan hipoksemia berat dengan perbandingan $\mathrm{PaO}_{2}$ dan $\mathrm{FiO}_{2}$ kurang dari 200 mendukung diagnosis ARDS.

Definisi ARDS menurut American European Consensus Conference (AECC) adalah sindrom akut, infiltrat difus pada kedua paru konsisten dengan edema paru, dan oksigenasi sistemik yang buruk, tanpa disertai adanya hipertensi arterial kiri. Sindrom ini disebur ALI jika rasio $\mathrm{PaO}_{2}$ dan $\mathrm{FiO}_{2}$ kurang dari 300, sedangkan jika kurang dari 200 disebut ARDS. Insidens ARDS diperkirakan 58,7 per 100.000 orang per tahun, kira-kira ada 141.500 kasus ARDS di Amerika Serikat setiap tahun. Mortalitas ARDS pada suatu studi disebutkan $41,1 \%{ }^{14}$

Inflamasi paru yang berat pada ARDS merupakan hasil dari cedera paru langsung dan tidak langsung. Penyebab langsung misalnya aspirasi cairan lambung, pneumonia dan drowning. Sedangkan penyebab tidak langsung misalnya keracunan obat, pankreatitis akut atau setelah transfusi. ${ }^{14}$ ARDS terjadi pada $40 \%$ pasien drowning dan terutama disebabkan efek toksik langsung air tawar pada epitel paru. ${ }^{8}$ Diagnosis klinis dengan adanya foto toraks yang khas, infiltrat pada kedua paru dengan edema paru, analisis gas darah memperlihatkan perbandingan $\mathrm{PaO}_{2}$ dan $\mathrm{FiO}_{2}$ kurang dari 200 dan juga dengan menggali faktor pencetus ARDS. Terapi pada ARDS terutama mengidentifikasi faktor pencetus dan mengobati faktor pencetus, dan keadaan yang mengancam jiwa. ${ }^{1}$

Pada kasus ini pasien datang dengan sesak napas akut, gambaran infiltrat luas di kedua paru, $\mathrm{PaO}_{2} / \mathrm{FiO}_{2}$ kurang dari 200, didiagnosis ARDS. Pada penilaian derajat drowning pasien masuk ke derajat 3, segera dilakukan intubasi dan pemberian ventilasi mekanik. Setelah stabilisasi di IRD pasien dirawat di ICU.

Pada kedokteran klinis, barotrauma merupakan manifestasi dari udara di luar alveoli selama pemakaian ventilator mekanik. Definisi lain barotrauma juga dikenal sebagai rupturnya paru akibat ekshalasi paksa, contoh pada cedera paru setelah deep sea dive.

Walaupun sering terjadi pada pasien tanpa penggunaan ventilasi mekanik, kasus yang paling banyak pada barotrauma terjadi pada pasien dengan ventilasi mekanik. Barotrauma hanya mewakili dari satu mekanisme yang mendasari terjadinya ventilator induced lung injury. ${ }^{17}$

Cedera paru pada barotrauma terkait dengan peningkatan tekanan alveolar. Insiden barotrauma pada pasien ARDS sangat tinggi, sekitar $87 \%$. Walaupun dilaporkan angka ini menurun pada dekade terakhir dikarenakan perubahan pendekatan pada pemakaian ventilasi mekanik. Sangat penting untuk memahami keterlibatan paru pada pasien ARDS beragam dan beberapa bagian paru lebih berat terkena dibanding bagian lain. Hal ini bisa mengakibatkan maldistribusi dari volume tidal mekanik, sehingga ada alveoli yang menerima distensi lebih dari alveoli lain. Distensi berlebih pada alveoli dapat menyebabkan rupture alveoli dan mengakibatkan pulmonary interstitial emphysema, pneumotoraks ataupun pneumomediastinum. Oleh karena itu seperti telah dijelaskan di atas penting untuk mengatur ventilasi mekanik dengan menyesuaikan tidal volume dan juga plateu pressure. Tidal volume 6-8 $\mathrm{kg} / \mathrm{IBW}$ akan mengurangi kejadian pneumotorak setelah pemasangan ventilator. ${ }^{14,17}$

Pada kasus ini terjadi pneumotoraks pada hari ke lima setelah pemasangan ventilasi mekanik, selain terkait dengan kondisi dasar ARDS, hal ini dapat juga dikarenakan tidal volume yang terlalu tinggi. Pasien segera ditangani dengan pemasangan chest tube+continuous suction, keadaan pasien membaik, 3 hari kemudian chest tube dilepas, paru sudah mengembang sempurna.

Pneumonia sering sulit dan salah didiagnosis karena gambaran awal foto toraks memperlihatkan gambar cairan pada paru dan tumpang tindih dengan gambaran ARDS. Pada beberapa kasus, pneumonia terjadi pada $12 \%$ kasus drowning dan memerlukan antibiotik. Antibiotik profilaksis tidak dianjurkan karena meningkatkan resistensi dan agresivitas kuman. Sebaiknya pasien dimonitoring setiap hari, dilihat apakah ada demam, leukositosis yang menetap, penambahan infiltrat dan pengambilan sampel kultur dahak. ${ }^{6,8}$ 
Onset dini pneumonia dapat dikarenakan aspirasi air yang kotor, flora endogen atau isi lambung. Aspirasi air kolam renang jarang mengakibatkan pneumonia. Risiko pneumonia meningkat selama pemasangan ventilator, dan bisa dideteksi pada hari ke 3 - 4 perawatan, saat edema paru sudah hampir pulih. Pneumonia sering dikarenakan patogen nosokomial. Saat diagnosis ditegakkan, antibiotik empiris spektrum luas harus segera diberikan, sampai hasil kultur dan sensitivitas obat didapatkan. Infeksi jamur dan kuman anaerob juga harus dipertimbangkan. ${ }^{1,10}$

Organisme penyebab pneumonia pada pasien drowning dapat berasal endogen, seperti Streptococcus pneumonia dan Haemophilus influenzae dan eksogen, misalnya Aeromonas. Burkholderia pseudomallei dilaporkan ditemukan di Filipina dan kadang ditemukan jamur, Pseudoallescheria boydii. ${ }^{8}$ Organisme lain penyebab pneumonia pada pasien drowning dapat dilihat pada tabel 1.

Pemberian terapi antibiotik pada pneumonia terkait drowning bisa diberikan penisilin spektrum luas dengan kombinasi anti beta laktamase atau cefalosporin, pada kasus yang sedang bisa ditambahkan aminoglikosida. Pemberian fluorokuinolon dan klindamisin juga rasional pada pasien alergi penisilin. Pemilihan antibiotik sangat tergantung dengan pengalaman lokal. ${ }^{8,11}$

Pada kasus ini pasien diberikan antibiotik sejak awal, dikarenakan kemungkinan terjadi aspirasi pneumonia. Terapi yang diberikan adalah levofloxacin dan metronidazole. Pertimbangan pemberian metronidazole berdasarkan kemungkinan penyebab kuman anaerob yang sering menjadi penyebab pada pneumonia aspirasi, namun kuman anaerob ini sulit dilakukan dan didapatkan hasil kulturnya. Sedangkan pertimbangan pemberian levofloxacin dikarenakan lokasi drowning adalah di kolam ikan air tawar yang mungkin banyak kontaminasi. Walaupun pada hasil kultur pertama tidak didapatkan kuman patogen, pada kultur kedua didapatkan kuman Klebisiella pneumonia, kuman ini bisa merupakan patogen nosokomial dari pemasangan ventilator. Namun karena secara klinis dan radiologis tidak menunjukkan pneumonia yang berat maka pasien diberikan terapi antibiotik oral sesuai hasil kultur.

Gangguan hemodinamik pada korban drowning mudah dikembalikan pada kondisi stabil dengan pemberian oksigen yang adekuat, infus kristaloid, dan tercapainya suhu tubuh normal. ${ }^{1,10}$ Jika penggantian volume dengan cairan kristaloid gagal maka dapat dilakukan ekokardiografi sebagai pertimbangan pemberian obat inotropik atau vasopresor atau keduanya. ${ }^{1}$

Hasil studi pada kelompok ARDS, Fluid and catheter treatment trial merekomendasikan pemasangan CVC pada pasien ARDS. ${ }^{12}$ Pasien ini juga dipasang CVC untuk monitoring keadaan hemodinamik. Pada hari ke dua perawatan terdapat tekanan darah yang cenderung turun, kemudian diberikan dopamin selama tiga hari. Selama perawatan tidak didapatkan gangguan hemodinamik yang berat.

Pada korban drowning dapat terjadi hipotermia dan dapat ditangani dengan rewarming yang meliputi penghangatan, menghindari obat-obat yang dapat mencetuskan fibrilasi ventrikel, humidified oksigen dengan tabung endotrakeal dan cairan yang dihangatkan melalui intra vena sentral. Kelainan neurologi yang permanen paling ditakutkan dari pasien yang selamat dari drowning. ${ }^{1}$ Kejang pada korban drowning paling baik dengan terapi suportif. Pemberian diazepam intra vena atau lorazepam efektif untuk kejang tetapi menekan level kesadaran dan respiratory drive. Kebanyakan korban mengalami perbaikan status neurologis dengan resusitasi. Namun jika status mental memburuk meskipun telah dilakukan resusistasi harus dicurigai adanya cedera kepala. ${ }^{16}$ Pada kasus ini tidak ada kejang dan tidak didapatkan defisit neurologik.

Pada kejadian stres akut atau trauma akut bisa terjadi peningkatan hormon-hormon counterregulatory, seperti glukagon, kortisol, katekolamin dan hormon pertumbuhan. Peningkatan hormon-hormon tersebut dapat mengakibatkan peningkatan lipolisis dan pemecahan protein, dan gangguan pemakaian glukosa oleh organ perifer. Maka terjadilah hiperglikemia. Stres hiperglikemia ditandai peningkatan glukosa darah sewaktu $>140 \mathrm{mg} / \mathrm{dl}$ tanpa riwayat diabetes melitus. Stres hiperglikemia akan teratasi ketika keadaan akut pada pasien teratasi. Pada kasus ini saat dilakukan pemeriksaan laboratorium didapatkan glukosa darah 286 $\mathrm{mg} / \mathrm{dl}$. Saat dilakukan pemeriksaan ulang ketika keadaan akut sudah ditangani hasil glukosa darah kembali normal (94 mg/dl). ${ }^{18}$

Prognosis secara langsung berkaitan dengan durasi dan besarnya hipoksia. Dampak paling signifikan pada morbiditas dan mortalitas terjadi sebelum korban tiba di rumah sakit. Berdasarkan derajat, pasien dengan derajat 6 hanya memiliki kemungkinan kecil untuk selamat, sedangkan derajat 5 56-69\% bisa selamat dan derajat 4 ke bawah mempunyai kemungkinan selamat yang makin besar. ${ }^{1}$ Lebih dari $80 \%$ pasien dengan non fatal drowning sembuh sempurna dan pulang ke rumah. Kurang lebih $10 \%$ menderita kelainan neurologi yang permanen dan $10 \%$ meninggal setelah rawat inap. ${ }^{2}$ Pada umumnya korban dengan foto toraks normal atau status mental normal mempunyai harapan untuk tetap bertahan hidup tanpa sequelae. Pasien ARDS mempunyai hasil keluaran yang baik pada tahun-tahun terakhir. Median penggunaan ventilator sekitar 9 hari, dan pasien dapat pulih. Derajat hipoksemia pada 24-48 jam pertama dari terjadinya ARDS memengaruhi keluaran. Morbiditas dan mortalitas pada barotrauma tergantung beratnya penyakit yang mendasari. Pneumotoraks memang dapat mengancam jiwa terutama jika tidak terdiagnosis dan tidak ditangani. Namun pneumotoraks tidak teridentifikasi sebagai penyebab menigkatnya angka mortalitas pada pasien ARDS. Prognosis dari pemulihan setelah barotrauma mempunyai hasil yang baik..$^{8,17}$

Pada kasus ini pasien selamat dari drowning, dengan derajat 3, secara klinis dan radiologis didiagnosis ARDS, pemberian segera oksigen yang adekuat dengan pemasangan ventilator memberi efek yang baik. Dari serial foto toraks tampak perbaikan. Walaupun pasien 
mengalami pneumotoraks setelah pemasangan ventilator, namun dengan penanganan yang tepat dan cepat, efek yang merugikan dapat dihindari. Pasien menggunakan ventilator selama 7 hari, kemudian menggunakan chest tube+continues suction 3 hari, pasien dirawat di rumah sakit selama 12 hari. Saat keluar rumah sakit kondisi pasien stabil tidak didapatkan defisit neurologik.

Pneumonia nosokomial khususnya ventilator-associated pneumonia (VAP) merupakan penyebab utama infeksi dan kematian di tempat perawatan. Pengobatan yang terlambat akan memberikan prognosis yang buruk. VAP sering disebabkan oleh kuman-kuman berikut, yaitu Pseudomonas aeruginosa, Haemophilus spp, Klebsiella spp atau Staphylococcus aureus. Pemberian terapi antibiotik harus sesuai dengan hasil kultur, sebelum hasil kultur didapatkan terapi berdasarkan terapi empirik. Pada VAP onset lambat, yaitu VAP terjadi lebih dari 5 hari setelah pemasangan endotracheal tube harus dipertimbangkan pemberian antibiotik untuk kuman multidrug resistance. ${ }^{19}$ Pada kasus ini, ditemukan kuman Klebsiella spp dari kultur sputum dan terapi diberikan sesuai hasil tes kepekaan obat.

\section{KESIMPULAN}

Telah dilaporkan kasus laki-laki usia 16 tahun yang mengalami drowning. Dari pemeriksaan fisis, laboratoris dan radiologis didapatkan edema paru, ARDS, dan pneumonia aspirasi. Pasien segera diberikan ventilasi mekanik, antibiotik dan dirawat di ICU. Pada hari ke lima setelah pemasangan ventilator mekanik pasien mengalami pneumotoraks kiri, dilakukan pemasangan chest tube selama tiga hari dan paru mengembang sempurna. Tidak ada defisit neurologik dan cedera pada organ lain. Berdasarkan klasifikasi drowning pasien sesuai dengan derajat 3 dan mempunyai prognosis yang baik. Pasien dirawat selama 12 hari dan pulang dalam keadaan baik. Lima bulan setelah rawat inap dilakukan kembali foto toraks dan didapatkan hasil yang baik, gambaran paru mengalami resolusi. Pasien sudah beraktivitas seperti biasa dan tidak mempunyai hambatan.

\section{DAFTAR PUSTAKA}

1. Szpilman D, Bierens Joost JLM, Handley Anthony J, Orlowski James P. Review article: Current concept Drowning. The New England Journal of Medicine. 2012; 366: 2101-10.

2. Plantadosi CA. Diving Medicine and Near Drowning. In: Crapo JD, Glassroth J, Karlinsky J, King TE eds, Baum's Text Book of Pulmonary Disease $7^{\text {th }}$ ed. Philadelphia Lippincort William \& wilkins. 2004; 1025-40.

3. Beeck EF. Van, Branche CM, Szpilman D, Modell JH, Bierens JJLM. A new definition of drowning: towards documentation and prevention of a global public health problem. Bulletin of the World Health Organization. 2005; 83: 853-856.

4. WHO fact about injuries. Drowning. Available at: www.who.int/ violence_injury_prevention/accessed on March 2013.

5. Morbidity and Mortality Weekly Report. Centers for Disease Control and Prevention (CDC). 2012;61(19): 344-347.

6. Carter Eleanor, Siclair Ray. Drowning. Continuing education in anaesthesia, critical care \&pain. 2011; vol 1;6.

7. Bierens JJLM. Handbook on Drowning. Springer. Jerman. 2006.

8. Ma We Jun, Nie Shao Ping, Xu Hao Feng, Xu Yan Jun et al. An analysis of risk factors on non fatal drowning among children in rural areas of Guangdong Province Chine: a case control study. BMC Public Health. 2010; 10: 156.

9. Sogoloff Helen, Ginsberg Robert. Unusual freshwater near drowning syndrome in a hospitalized postlobectomy patient. CHEST. 2001; 120: 3 .

10. Bove AA, Neuman T. Diving Medicine. In: Murray JF, Nadel JA eds. Text Book of Respiratory Medicine, $3^{\text {rd }}$ ed. WB Saunders Company, Philadelphia. 2000; 1964-67.

11. Ender PT, Dolan MJ. Pneumonia Associated with Near Drowning. Clin Infect Dis. 1997; 25: 896-907.

12. Wallace JF. Drowning and Near Drowning. In: Wilson JD, Braunwald E, Isselbacher KJ et al. Harisons Principle of Internal Medicine. $12^{\text {th }}$ ed. Newyork, McGraw-Hill. Inc. 1991; 2200-2.

13. Fraser RS, Pare JAP et al. Synopsis Disease of the Chest. $3^{\text {rd }}$ ed, WB Saunders Co, Philadelphia. 1988; 739-51.

14. Christie Jason D, Lanken Paul N. Acute lung injury and the acute respiratory distress syndrome: Clinical features, management, and outcomes. In: Fishman Alfred P, Elias Jack A, Fishman Jay A, Grippi Michael A, et al. Fishman's Pulmonary disease and disorders. $4^{\text {th }}$ ed. McGraw-Hill. Philadelphia. 2008; 2535-60.

15. Cohen R. Disorder due to Physical Agent. In: Tiennay LM, Mc Phee SJ, Papadakis MA eds. Current Medical Diagnosis and Treatment. The McGraw-Hill. Newyork. 2001; 1536-54.

16. Thanel F. Near Drowning. Post Graduate Medicine. 1998; 103: 6.

17. Hoo Guy W Soo et al. Barotrauma and Mechanical Ventilation. Available at: www.medscape.com accessed on July 2013.

18. Farrokhi F, Smiley D, Umpierrez GE. Glycemic control in nondiabetic critically ill patients. Best practice \& research clinically endocrinology \& metabolism. 2011; 813-24.

19. Aya B.HD, Rello J. Aetiopathogenesis of VAP revisited. Eur Respir Mon 2011; 53, 1-10. 